CLINICAL HEMORHEOLOGY, Vol. 13, pp. 145, 1993

$0271-5198 / 93 \$ 6.00+.00$ Printed in the USA.

Copyright $\odot 1993$ Pergamon Press Ltd. All rights reserved.

\title{
CONTENTS OF BIORHEOLOLGY
}

VOLUME 29, NUMBER 4

JULY-AUGUST 1992

CONTENTS

iii Announcement

Papers

P. Chiarelli, P.J. Basser, D. DeRossi

383 The dynamics of a hydrogel strip

and S. Goldstein

H.D. Papenfuss, J.F. Gross and

399 Mathematical model of the filtration in the vascular network of the ophidian glomerulus

T. Matsumoto, M. Kawai and T. Masuda

411 Influence of concentration and mannuronate/ gluronate ratio on steady flow properties of alginate aqueous systems

D. Liepsch, M. Singh and M. Lee

419 Experimental analysis of the influence of stenotic geometry on steady flow

G. Lorenzi, G.M. Böhm, E.T. Guimarães, 433 Correlation between rheologic properties and in vitro M.A. Costa Vaz, M. King and P.H.N. Saldiva ciliary transport of rat nasal mucus

441 Contents of Clinical Hemorheology,

Volume 11, Number 5 